\title{
Kajian Awal Material Pembuat Toe cap (Safety shoes) Menggunakan Metode Elemen Hingga
}

\author{
Hendrix Noviyanto Firmansyah", Ayub Budhi Anggoro' dan Eni Safriana ${ }^{2}$ \\ ${ }^{1}$ Teknik Mesin, Universitas Negeri Semarang, \\ Sekaran, Gunungpati, Semarang \\ ${ }^{2}$ Teknik Mesin, politeknik Negeri Semarang, \\ Jl. Prof. H. Soedarto S.H., Tembalang, Semarang \\ *E-mail: hendrix@mail.unnes.ac.id
}

Diterima: 20 September 2021; Direvisi: 15 Desember 2021; Dipublikasi: 30 Desember 2021

\begin{abstract}
Abstrak
Toe cap merupakan bagian utama dari safety shoes sebagai pelindung diri dari tertimpa benda saat bekerja. Beragam jenis material dapat digunakan dalam pembuatan Toe cap asal memenuhi persyaratan salah satunya adalah mampu menahan beban tekan sebesar 15.000 N. Persyaratan yang lainnya adalah dapat menahan beban impak sebesar 200J. Pada penelitian ini dilakukan kajian mengenai jenis material apa saja yang cocok untuk dijadikan bahan pembuat Toe cap. Metode yang digunakan dalam penelitian ini adalah dengan membuat model sederhana dalam perangkat lunak MSC Patran/nastran dan memasukkan material yang selanjutnya dilakukan analisa untuk mendapatkan parameter tegangan, masa dan defleksi toe cap . Material yang digunakan adalah steel, aluminum, carbon/epoxy, e-glass/ epoxy, dan kevlar/epoxy. Analisa menunjukkan bahwa material steel memiliki kemampuan paling baik, namun memiliki berat yang paling besar juga. Selain steel kandidat yang aman lainnya adalah aluminum dan carbon/epoxy. Sedangkan material e-glass/ epoxy dan kevlar/epoxy menurut kriteria Tsai Wu terjadi kegagalan pada layer 5 \&1. Berdasarkan pada nilai keamaan, masa dan defleksi, maka carbon/epoxy adalah pilihan yang terbaik.
\end{abstract}

Kata kunci: Toe cap ; variasi material; komposit; Tsai Wu; MSC Patran/Nastran.

\begin{abstract}
Toe cap is the main part of safety shoes as self-protection from falling objects while working.. Various types of materials can be used in the manufacture of Toe cap s as long as they meet the requirements, one of which is being able to withstand a compressive load of 15,000 N. Another requirement is to be able to withstand an impact load of 200J. This study was conducted to determine the suitable material for making Toe cap s. The method was by creating model in MSC Patran/Nastran, then put the materials properties into model so can be analiyzed to gain the parameter of stress, mass and Toe cap deflection. The materials used in this study are steel, aluminum, carbon/epoxy, glass epoxy, and kevlar/epoxy. The results shows that the steel material has the best capability, but has the largest weight as well. Besides steel, other safe candidates are aluminum and carbon/epoxy. Meanwhile, the glass/epoxy and kevlarlepoxy materials according to Tsai Wu's criteria fail at layers 5 \& 1 . Based on the value of safety, mass and deflection, it waswas decided that carbon/epoxy is the best choice.
\end{abstract}

Keywords: (Toe cap ; material variatio; composit; Tsai Wu; MSC Patran/Nastran.

\section{Pendahuluan}

Kesehatan serta Keselamatan Kerja (K3) menjadi perhatian yang tinggi bagi Pemerintah, ini dilihat dari telah dibuatnya Undang-undang 1 Tahun 1970 tentang keselamatan kerja yang kemudian dilengkapi dengan peraturan pemerintah. Peraturan Menteri 5 Tahun 2018 tentang Keselamatan dan Kesehatan Kerja Lingkungan Kerja berisi mengenai keselamatan dan kesehatan tenaga kerja melalui pencegahan kecelakaan kerja dan penyakit akibat kerja dengan menetapkan kewajiban bagi pengusaha dan/atau pengurus untuk memenuhi syarat keselamatan dan kesehatan lingkungan kerja/K3. Kemudian Peraturan pemerintah terbaru PP No.88 Tahun 2019 Tentang Kesehatan Kerja yang berisi Pemerintah Pusat, Pemerintah Daerah dan masyarakat diharuskan untuk bertanggung jawab dalam penyelenggaraan Kesehatan Kerja secara terpadu, menyeluruh dan berkesinambungan. Meskipun demikian, kasus kecelakan kerja di Indonesia masih relatif tinggi. Merujuk data BPJS Ketenagakerjaan, pada tahun 2019 terdapat 114 ribu kasus kecelakaan kerja. Tahun 2020 angka ini meningkat, di mana pada rentang Januari hingga Oktober 2020, 
BPJS Ketenagakerjaan mencatat terdapat 177 ribu kasus kecelakaan kerja. Kasus kecelakaan kerja pada pegawai pabrik masih didominasi oleh kasus tenaga kerja diusia produktif yang memiliki kompetensi rendah. Untuk menekan angka kecelakaan kerja dan melindungi pekerja, langkah yang tepat adalah dengan selalu menggunakan Alat Pelindung Diri (APD) di tempat kerja sesuai dengan bidang pekerjaannya. Ini berarti tidak boleh adanya toleransi dalam penggunaan alat pelindung diri. Alat Pelindung Diri (APD) adalah suatu alat yang mempunyai kemampuan untuk melindungi seseorang yang fungsinya mengisolasi sebagian atau seluruh tubuh dari potensi bahaya di tempat kerja. Jenis-jenis APD meliputi, pelindung kepala, pelindung mata dan muka, pelindung telinga, pelindung pernapasan beserta perlengkapannya, pelindung tangan; dan pelindung kaki.

Alat pelindung kaki berfungsi untuk melindungi kaki dari tertimpa atau berbenturan dengan benda-benda berat, tertusuk benda tajam, terkena cairan panas atau dingin, uap panas, terpapar suhu yang ekstrim, terkena bahan kimia berbahaya dan jasad renik, tergelincir. Kejadian kecelakaan tertimpanya kaki saat bekerja dikarenakan masih banyaknya pekerja yang belum menggunakan Safety shoes (sepatu untuk keamanan kaki). Pekerja masih menggunakan sepatu yang regular (bisa) tanpa adanya penggunaan pelindung jari pada ujung sepatu. Mereka beralasan bahwa sepatu tersebut tidak nyaman, berat dan memiliki harga yang mahal. Hal itu beralasan karena sebagian besar bahan pembuat dari pelindung jari kaki terbuat dari logam (metal) yang berkemampuan tinggi. Jenis metal yang digunakan adalah steel dan aluminum. Untuk mengurangi berat sepatu, terdapat rancangan safety shoes yang menggunakan material dari polimer dan komposit. Namun pelindung yang terbuat dari polimer tidak dapat menandingi kekuatan metal dan komposit. Serat karbon merupakan salah satu jenis material yang digunakan untuk mendapatkan kekuatan dan berat yang diinginkan. Namun karena itulah safety shoes yang menggunakan komposit serat karbon memiliki harga yang mahal. Harga serat karbon yang mahal karena serat tersebut tidak tersedia di alam secara langsung, namun diperoleh dengan proses produksi yang menggunakan teknologi tinggi dan biaya yang besar. Selain serat gelas terdapat serat gelas yang juga memiliki Kemampuan yang baik dan relatif lebih murah dari pada serat karbon, sehingga bisa digunakan jika ingin mengurangi biaya produksi. Terlepas dari jenis material apa yang digunakan, suatu pelindung jari kaki (Toe cap s) harus memenuhi persyaratan. Persyaratan yang harus dipenuhi adalah minimal mampu menahan beban impak sebesar $200 \mathrm{~J}$, dan beban kompresi sebesar 15 kN (EN ISO 20345:211). Pada penelitian ini dilakukan kajian jenis material yang sesuai untuk pembuatan Toe cap dengan pembebanan tekan $15000 \mathrm{~N}$.

\section{Tinjauan Pustaka}

Pelindung jari kaki (Toe cap s) merupakan komponen alat pelindung kaki yang terpasang pada sepatu. Toe cap s ini berfungsi melindungi jari kaki dari benda-benda yang jatuh saat melakukan aktifitas atau pekerjaan. Jenis material yang digunakan sangat bervariasi, dimulai dari matal, polimer dan komposit. Toe cap s yang melindungi kaki juga dapat terbuat dari material polimer Toe cap s dapat terbuat dari polikarbonat (PC), akrilonitril butadienastiren (ABS) dan polipaduan $\mathrm{PC} / \mathrm{ABS}$ memiliki Kemampuan yang bervariasi. Menurut hasil penelitian, jenis polipaduan PC/ABS memiliki kemampuan yang terbaik dibanding dengan policarbonat (PC) dan akrilonitril butadienastiren (ABS) ( Dwi Wahini Nurhajati, dkk, 2016). Bukan hanya sebagai pencegah terlukanya kaki akibat kecelakan Toe cap juga digunakan untuk melindungi jari kaki yang terluka. Toe cap didesain dari bahan fabric yang berfungi sebagai pengganti perban dengan kelebihan dapat digunakan beberapa kali sehingga menghemat uang (Rebecca Elwell \& Jane Wigg, 2015). Penggunaan Toe cap berbahan steel memberikan perlindungan masih merupakan suatu pilihan. (Sérgio L.CostaJoão, dkk, 2016) melakukan penelitian mengenai Toe cap s berbahan high strength steel untuk dapat menahan beban yang disyaratkan dengan berat seringan mungkin. Akan tetapi Toe cap s yg terbuat dari steel masih berat jika 
dibandingkan komposit (serat). Jika dibandingkan antara steel Toe cap dan kompsoit Toe cap , akan tampak seperti pada tabel 1 .

Tabel 1. Perbandingan Toe cap berbahan dasar steel vs komposit

\begin{tabular}{lll}
\hline Jenis material & Kelebihan & Kekurangan \\
\hline Steel & - harga lebih burah & - lebih berat dari komposit \\
& - kuat, dan bahkan dapat lebih kuat dari & - dapat tepengaruh suhu lingkungan \\
& komposit & - dapat menghantarkan listrik \\
- & sudah teruji & \\
- & memiliki banyak model, ukuran, dan bentuk & \\
& & \\
\hline Komposit & Ringan dan memiliki ketahanan yang baik & - Karena memiliki spesifikasi yang \\
& - Tidak terpengaruh terhadap suhu & tinggi menyebabkan harganya lebih \\
& lingkungan & mahal \\
- & Tidak dapat menghantarkan listrik & Tidak banyak memiliki model, \\
& & ukuran dan bentuk \\
\hline
\end{tabular}

Komposit berbahan dasar serat dapat dibedakan menjadi komposit serat alam dan serat sintetis. Variasi serat sintetis komposit sudah banyak dilakukan, dan memiliki hasil yang bervariasi. Serat E-glass, carbon, dan aramid fabrics juga telah digunakan pada penelitian pembuatan Toe cap. Serat tersebut digabungkan dengan resin epoxy dengan gabungan (hybrid) dari ketiga serat tersebut (Aramid/Carbon/Glass). Variasi yang digunakan berdasarkan konfigurasi susunan (serat), arah dan jumlah layer. Hasil pengujian menunjukkan bahwa penggunaan susunan hybrid simetris dengan jumlah layer paling banyak (16 layer) memiliki Kemampuan menahan beban yang diberikan (Seçkin Erden \& Mustafa Ertekin, 2017). Pada penelitian ini akan menggunakan metode elemen hingga untuk menentukan material awal yang mungkin akan dijadikan model pertimbangan dalam pembuatan toe cap. Hasil dari distribusi tegangan pada tiap kondisi pemodelan akan dijadikan referensi dalam membuat konfigurasi susunan toe cap yang nantianya akan diuji lab.

\section{Metodologi}

Langkah pertama yang dilakukan pada penelitian ini adalah menentukan model Toe cap dan membuat model dengan Finite Element Method (FEM). Model FEM dibuat dengan menggunakan perangkat lunak MSC Patran. Langkah selanjutnya adalah menentukan jenis material yang akan dibuat. Pada penelitian ini jenis material yang akan digunakan adalah steel, aluminum, carbon/epoxy, e-glass epoxy dan Kevlar/epoxy. Jenis serat fabric dipilih karena ingin memudahkan pada saat nanti dalam pembauatan prototype, selain itu nilai kekuatan pada arah x dan y cenderung sama. Table 2 merupakan tabel mekanikal property material yang digunakan pada penelitian ini.

Tabel 2. Mekanikal propertis material (http://www.performance-composites.com/carbonfibre/mechanicalproperties_2.asp)

Fibres @ $0^{\circ}$ (UD), 0/90 ${ }^{\circ}$ (fabric) to loading axis, Dry, Room Temperature, $\mathrm{Vf}=60 \%$ (UD), $\mathbf{5 0 \%}($ fabric)

Symbol Units

\begin{tabular}{lllll} 
Std CF & E glass & Kevlar & Steel & $A l$, \\
\hline Fabric & Fabric & Fabric & S97 & L65
\end{tabular}


Hendrix Noviyanto Firmansyah dkk /Jurnal Rekayasa Mesin p-ISSN: 1411-6863, e-ISSN: 2540-7678

Vol.16|No.3|379-390|Desember|2021

\begin{tabular}{|c|c|c|c|c|c|c|c|}
\hline Young's Modulus $0^{\circ}$ & E1 & GPa & 70 & 25 & 30 & 207 & 72 \\
\hline Young's Modulus $90^{\circ}$ & E2 & $\mathrm{GPa}$ & 70 & 25 & 30 & 207 & 72 \\
\hline In-plane Shear Modulus & G12 & $\mathrm{GPa}$ & 5 & 4 & 5 & 80 & 25 \\
\hline Major Poisson's Ratio & v12 & & 0,1 & 0,2 & 0,2 & & \\
\hline${\text { Ult, Tensile Strength } 0^{\circ}}^{\circ}$ & $\mathrm{Xt}$ & $\mathrm{MPa}$ & 600 & 440 & 480 & 990 & 460 \\
\hline Ult, Comp, Strength $0^{\circ}$ & $\mathrm{Xc}$ & $\mathrm{MPa}$ & 570 & 425 & 190 & & \\
\hline Ult, Tensile Strength $90^{\circ}$ & $\mathrm{Yt}$ & $\mathrm{MPa}$ & 600 & 440 & 480 & & \\
\hline Ult, Comp, Strength $90^{\circ}$ & Yc & $\mathrm{MPa}$ & 570 & 425 & 190 & & \\
\hline Ult, In-plane Shear Stren, & $\mathrm{S}$ & $\mathrm{MPa}$ & 90 & 40 & 50 & & \\
\hline Ult, Tensile Strain $0^{\circ}$ & ext & $\%$ & 0,85 & 1,75 & 1,6 & & \\
\hline Ult, Comp, Strain $0^{\circ}$ & exc & $\%$ & 0,8 & 1,7 & 0,6 & & \\
\hline Ult, Tensile Strain $90^{\circ}$ & eyt & $\%$ & 0,85 & 1,75 & 1,6 & & \\
\hline Ult, Comp, Strain $90^{\circ}$ & eyc & $\%$ & 0,8 & 1,7 & 0,6 & & \\
\hline Ult, In-plane shear strain & es & $\%$ & 1,80 & 1,00 & 1,00 & & \\
\hline Density & & $\mathrm{g} / \mathrm{cc}$ & 1,60 & 1,90 & 1,40 & & \\
\hline
\end{tabular}

Model yang digunakan hanyalah 1 jenis model yang dibuat dan dilakukan analisis menggunakan perangkat lunak MSC Patran/Nastran. Langkah pemodelan dilakukan dengan membuat sketsa ukuran kaki dan membuatnya diprangkat lunak. Ukuran model yang digunakan adalah panjang $120 \mathrm{~mm}$, lebr $8 \mathrm{~mm}$, dan tinggi $5 \mathrm{cmm}$. Untuk memudahkan pemodelan dan analisis awal ini, model dibuat rata atas dan bentuk pada bagian depan menyesuaikan ukuran jari kaki.

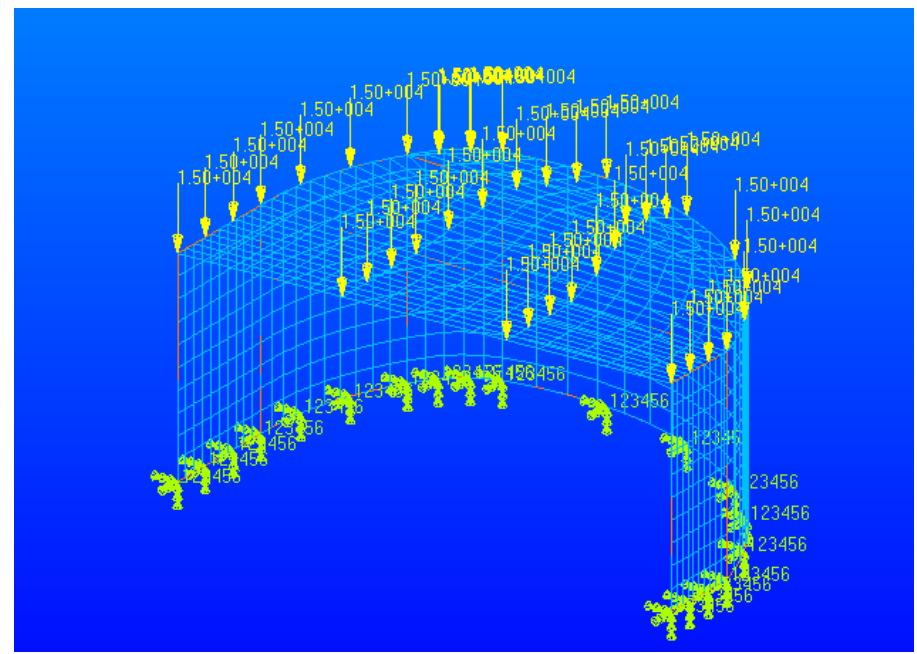

Gambar 1. Model Toe cap

Langkah berikutnya adalah memasukkan material tersebut kedalam model dan melengkapi dengan tumpuan dan beban. Beban yang diberikan berupa tekan sebesar $15000 \mathrm{~N}$ yang disebarkan pada permukaan model. Model dapat dilihat pada gambar 1. Setelah itu model dapat dilkaukan analisis, untuk melihat informasi yang diinginkan seperti tegangan, deformasi, masa dan sebaran tegangan yang terjadi. Nilai tegangan tersebut dapat digunakan untuk mencari Margin of Safety (MS). Nilai MS digunakan untuk mengetahui apakah Toe cap tersebut aman atau tidak. Aman jika 
nilai MS lebih atau sama dengan 0. MS digunakan untuk analisis keamanan bagi material isotropic (steel dan Aluminum)Berikut adalah persamaannya.

$$
M S=\frac{\sigma_{u l t}}{\sigma_{\text {all }}}-1
$$

Pada komposit laminat, kegagalan dilihat berdasarkan kriteria kegagalan Tsai Wu. Kegagalan terjadi jika nilai Failure Indices (FI) sama atau lebih dari 1. Berikut adalah persamaan yang digunakan.

$$
F_{1} \sigma_{1}+F_{2} \sigma_{2}+F_{11} \sigma_{1}^{2}+F_{22} \sigma_{2}^{2}+2 F_{12} \sigma_{1} \sigma_{2}+F_{66} \sigma_{12}^{2}=1
$$

$$
\begin{aligned}
& F_{1}=\frac{1}{X_{t}}-\frac{1}{X_{c}} \\
& F_{2}=\frac{1}{Y_{t}}-\frac{1}{Y_{c}} \\
& F_{11}=+\frac{1}{X_{t} X_{c}}
\end{aligned}
$$

$$
\begin{gathered}
F_{22}=+\frac{1}{Y_{t} Y_{c}} \\
F_{66}=+\frac{1}{S^{2}}
\end{gathered}
$$

\section{Pembahasan dan Diskusi}

\subsection{Toe cap dengan material steel}

Tegangan von mises maksimum terjadi sebesar $284 \mathrm{Mpa}$ dan terjadi pada bagian sudut atas Toe cap . Dari hasil tegangan tersebut didapatkan nilai MS 2,485, yang artinya adalah aman. Displacement maksimum terjadi pada bagian atas Toe cap yaitu sebesar 0,622 mm. Masa Toe cap dengan penggunaan material steel sebesar 7,505134E-001 kg dan masih terasa berat. Ini dikarenakan model Toe cap memiliki ketebalan yang merata sebear $5 \mathrm{~mm}$.



Gambar 2. Distribusi tegangan Toe cap berbahan material steel

\subsection{Toe cap dengan material aluminum}

Distribusi tegangan pada Toe cap yang menggunakan material aluminum memiliki pola dan nilai yang hampir sama seperti steel. Ini dikarenakan steel dan aluminum merupakan material isotropik, sehingga perilaku material cenderung sama. Nilai tegangan von mises maksimum yang sebesar 283 MPa masih aman, karena hasil perhitungan MS didapatkan nilai 0,625. Displacement maksimum sebesar 1,8 mm, dan lebih besar daripada Toe cap yang berbahan 
Hendrix Noviyanto Firmansyah dkk /Jurnal Rekayasa Mesin p-ISSN: 1411-6863, e-ISSN: 2540-7678

Vol.16|No.3|379-390|Desember|2021

material steel. Ini dikarenakan nilai elastic modulus aluminum yang lebih kecil jika dibandingkan dengan steel. Sedangkan masa aluminum lebih kecil jika dibandingkan dengan steel, yaitu sebesar 2,666298E-001 kg.

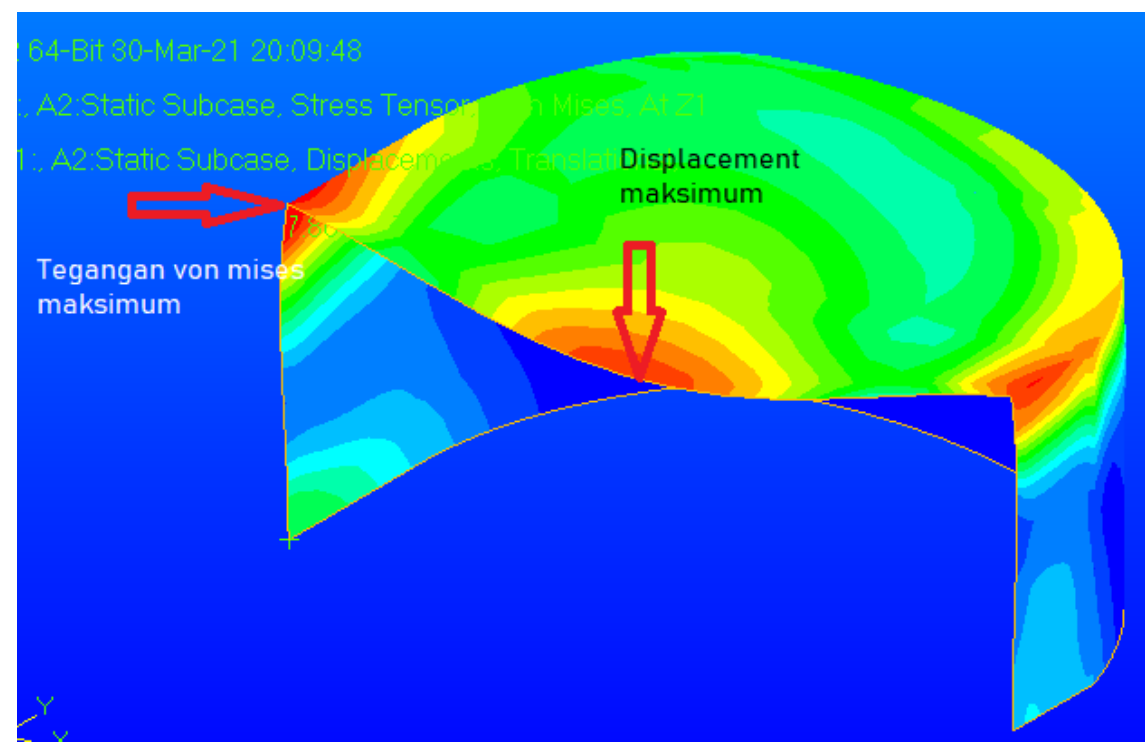

Gambar 3. Distribusi tegangan Toe cap berbahan material aluminum

\subsection{Toe cap dengan material carbon/epoxy}

Penggunaan jenis bahan material carbon/epoxy, dibuat dalam 2 susunan laminat yang memiliki ketebalan total yang sama $5 \mathrm{~mm}$. Kedua susunan tersebut adalah susunan arah 0/0/90/0/0 yang akan disebut sebagai LCa, dan susunan arah 0/45/90/-45/0 disebut sebagai LCb. Untuk masa Toe cap berbahan ini adalah 1,580028E-001 kg.

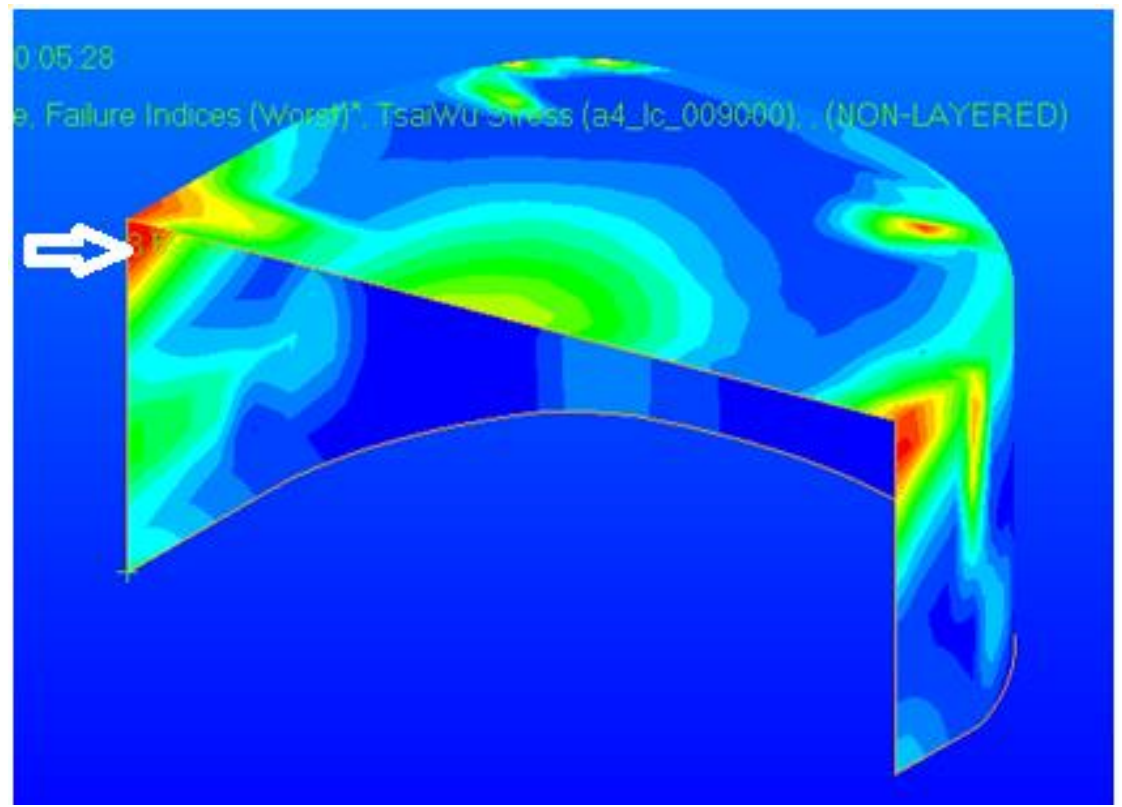

Gambar 4. Distribusi tegangan Toe cap berbahan material carbon/epoxy

Pada LCa, nilai tegangan von mises maksimal terjadi pada laminat 5 dengan nilai $333 \mathrm{MPa}$. Letak tegangan tersebut sama seperti pada penggunaan bahan material steel maupun aluminum. Distribusi tegangan layer sama, kecuali layer 3. 
Hendrix Noviyanto Firmansyah dkk /Jurnal Rekayasa Mesin

p-ISSN: 1411-6863, e-ISSN: 2540-7678

Vol.16|No.3|379-390|Desember|2021

Ini dikarenakan arah layer 3 berbeda dengan layer lainnya, yaitu 90 deg. Pada layer 3 nilai tegangan yang terjadi adalah yang paling kecil dan terletak pada tepian vertical bagian kanan Toe cap . Besarnya tegangan von mises tersebut adalah 81,8 MPa. Jika dilihat dari tingkat distribusi tegangan yang terjadi, layer yang kritis adalah layer 5 \& 1 . Sedangkan secara keseluruhan Toe cap dengan susunan LCa ini masih aman dengan diketahuinya nilai FI maksimal sebesar 0,359. Displacement susunan LCa sebesar 2,35 mm.

Susunan LCb memiliki distribusi tegangan yang lebih besar daripada LCa pada layer 5, 1, \& 3, namun kecil pada layer 2 ( $45 \mathrm{deg})$ dan 4 (-45 deg). Ini dikarenakan arah layer 45/-45 tidak menerima beban secara maksimal seperti pada arah serat 0 deg. Nilai tegangan von mises maksimal yang terjadi pada layer 5 sebesar $364 \mathrm{MPa}$ dan untuk displacement maksimum adalah sebesar 2,37 mm. Pada susunan LCb, layer yang kritis sama seperti LCa yaitu layer 5 \& 1 , sedangkan nilai FI sebesar 0,385. Masa susunan LCb juga sama seperti LCa.

\subsection{Toe cap dengan material e-glass epoxy}

Penggunaan e-glass epoxy pada Toe cap ini divariasikan menjadi 2 susunan laminat, yaitu susunan arah 0/0/90/0/0 yang akan disebut sebagai LGa, dan susunan arah 0/45/90/-45/0 disebut sebagai LGb. Besarnya masa LGa dan LGb sama, yiitu 1,876284E-001 kg. Pada susunan LGa, tegangan von mises maksimum yang terjadi sebesar 308 MPa. Tegangan yang terjadi menyebabkan kegagalan pada layer $5 \& 1$. Kegagalan pada layer 5 ditandai dengan nilai FI bernilai lebih dari 1, yaitu sebesar 1,49. Sedangkan kegagalan layer 1 diketahui dengan nilai FI sebesar 1,04. Kegagalan disebabkan tegangan geser yang terjadi lebih besar dari kemampuan material. Layer lainnya selain kedua layer tersebut masih aman (layer 2, 3, dan 4). Displacement maksimum LGa sebesar 5,99 mm.

Tegangan von mises maksimum pada susunan LGb sebesar 326 MPa yang terjadi pada layer 5 seperti pada susunan LGa. Namun kegagalan yang terjadi pada susunan LGb hanya pada layer 5. Kegagalan tersebut dikarenakan terdapat nilai tegangan geser yang melebihi Kemampuan material. Tegangan geser yang terjadi sebesar 40,9 MPa, atau 0,9 $\mathrm{MPa}$ lebih besar daripada tegangan geser material. Nilai FI layer 5 sebesar 1,16, sedangkan untuk layer lainnya masih aman. Displacemet yang terjadi pada LGb ini sebesar 6,08 mm, sedikit lebih besar daripada LGa.

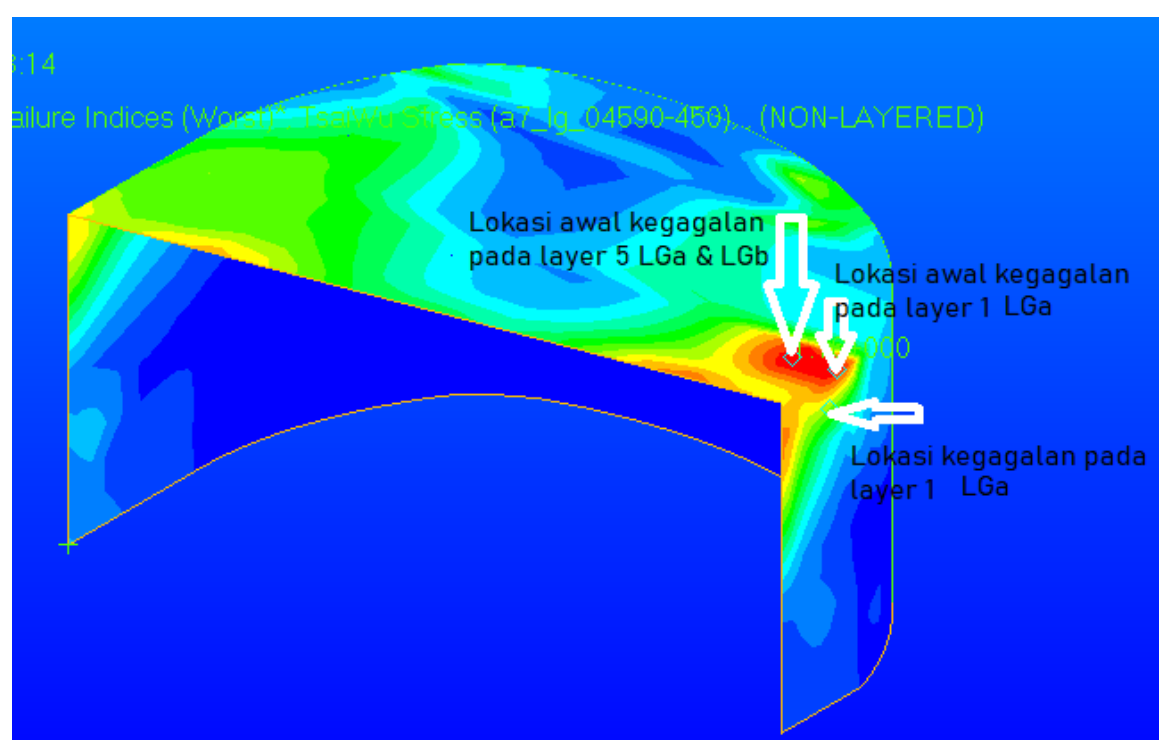

Gambar 5. Lokasi kegagalan Toe cap berbahan material e-glass epoxy 
Hendrix Noviyanto Firmansyah dkk /Jurnal Rekayasa Mesin p-ISSN: 1411-6863, e-ISSN: 2540-7678 Vol.16|No.3|379-390|Desember|2021

\subsection{Toe cap dengan material kevlar/epoxy}

Toe cap berbajan kevlar/epoxy memiliki susunan lamina sama seperti carbon/epoxy dan e-glass epoxy. Susunan 0/0/90/0/0 disebut sebagai LKa, sedangkan susunan 0/45/90/-45/0 disebut sebagai LKb. Masa Toe cap pada kedua susunan LKa \& LKb yaitu sebesar 1,382525E-001 kg. Susunan Lka memiliki nilai tegangan von mises maksimal sebesar $307 \mathrm{MPa}$. Pada layer ke-5 tersebut juga terjadi kegagalan yang dikarenakan tegangan tekan sebesar $311 \mathrm{MPa}$ terjadi pada tepian kiri Toe cap . Nilai FI layer 5 adalah 2,14. Layer 1 juga mengalami kegagalan dengan nilai FI sebesar 1,39. Sedangkan layer selain kedua layer tersebut menunjukkan kondisi aman, dengan nilai FI kurang dari 1. Besarnya displacement LKa adalah 4,95 mm.

Tegangan von mises pada susunan LKb adalah $324 \mathrm{MPa}$ dan memiliki pola yang sama seperti LKa, yaitu terdapat 2 layer yang gagal berdasarkan nilai failure indicies. Layer tersebut adalah layer ke-5 dengan nilai failure indicies 2,2 dan layer ke-1 dengan nilai failure indicies 1,4. Kegagalan pada layer ke-5 dikarenakan tegangan tekan sebesar $317 \mathrm{Mpa}$ melebihi kemampuan material. Tegangan ini terjadi di titik tepian Toe cap bagian kiri. Sedangkan displacementnya $5,03 \mathrm{~mm}$. Setelah dilakukan analisis pada masing-masing jenis bahan, Tabel 2 berikut adalah tabel ringkasan hasil analisisnya.

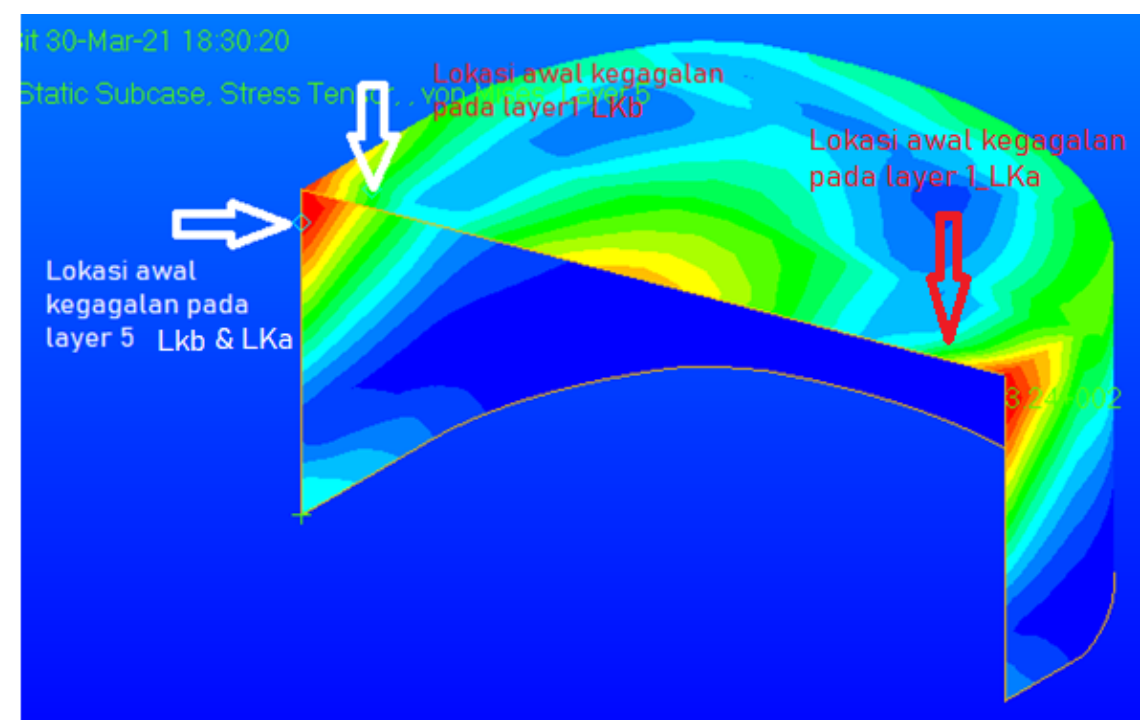

Gambar 6. lokasi kegagalan Toe cap berbahan material kevlarlepoxy

Tabel 2. Ringkasan hasil analisis Toe cap dengan variasi jenis material

\begin{tabular}{|c|c|c|c|c|c|}
\hline No & Bahan & $\begin{array}{l}\text { Massa } \\
(\mathbf{k g})\end{array}$ & $\begin{array}{l}\text { Tegangan } \\
\text { Max (MPa) }\end{array}$ & $\begin{array}{l}\text { Defleksi } \\
(\mathrm{mm})\end{array}$ & $\begin{array}{l}\text { Keterangan } \\
\text { Failure Indicies (FI) Tsai Wu }\end{array}$ \\
\hline 1 & Steel & 7.505134E-001 & 284 & 0,622 & \multirow{5}{*}{$\begin{array}{l}\text { Aman } \\
\text { MS 2,485 } \\
\text { Aman } \\
\text { MS } 0,625 \\
\text { Aman } \\
\text { FI 0,359 } \\
\text { Aman } \\
\text { FI 0,385 } \\
\text { Layer 5, FI 1,49 gagal } \\
\text { Layer 1, FI } 1, .04 \text { gagal } \\
\text { Layer 2, 3, \& } 4 \text { aman }\end{array}$} \\
\hline 2 & Aluminum & $2.666298 \mathrm{E}-001$ & 283 & 1,8 & \\
\hline & $\begin{array}{l}\text { Carbon/epoxy } \\
\mathrm{LCa} 0 / 0 / 90 / 0 / 0\end{array}$ & & 333 & 2,35 & \\
\hline 3 & $\begin{array}{l}\text { Carbon/epoxy } \\
\text { LCb 0/45/90/-45/0 }\end{array}$ & $1.580028 \mathrm{E}-001$ & 364 & 2,37 & \\
\hline 4 & $\begin{array}{l}\text { E-glass epoxy } \\
\text { LG } 0 / 0 / 90 / 0 / 0\end{array}$ & $1.876284 \mathrm{E}-001$ & 308 & 5,99 & \\
\hline
\end{tabular}


Hendrix Noviyanto Firmansyah dkk /Jurnal Rekayasa Mesin p-ISSN: 1411-6863, e-ISSN: 2540-7678

Vol.16|No.3|379-390|Desember|2021

E-glass epoxy

LG 0/45/90/-45/0

Kevlar/epoxy

LK 0/0/90/0/0

5

Kevlar/epoxy

LK 0/45/90/-45/0
326

307

$1.382525 \mathrm{E}-001$
6,08

4,95

5,03
Layer 5, FI 1,16 gagal

Layer $1 \mathrm{~s} / \mathrm{d} 4$ aman

Layer 5, FI 2,14 gagal

Layer 1, FI 1,39 gagal

Layer 2, 3, \& 4 aman

Layer 5, FI 2,2 gagal

Layer 1, FI 1,4 gagal

Layer 2, 3, \& 4 aman

Berdasar pada hasil analisis, grafik masa Toe cap dengan variasi bahan dapat dilihat pada Gambar 7. Pada Gambar 7 dapat dilihat bahwa steel memiliki masa yang paling besar diantara semua bahan yang digunakan, sedangkan Kevlar/epoxy adalah masa yang terkecil. Ini dikarenakan steel memiliki densitas paling besar diantara bahan yang digunakan, sedangkan model yang digunakan memiliki dimensi dan ketebalan yang sama.

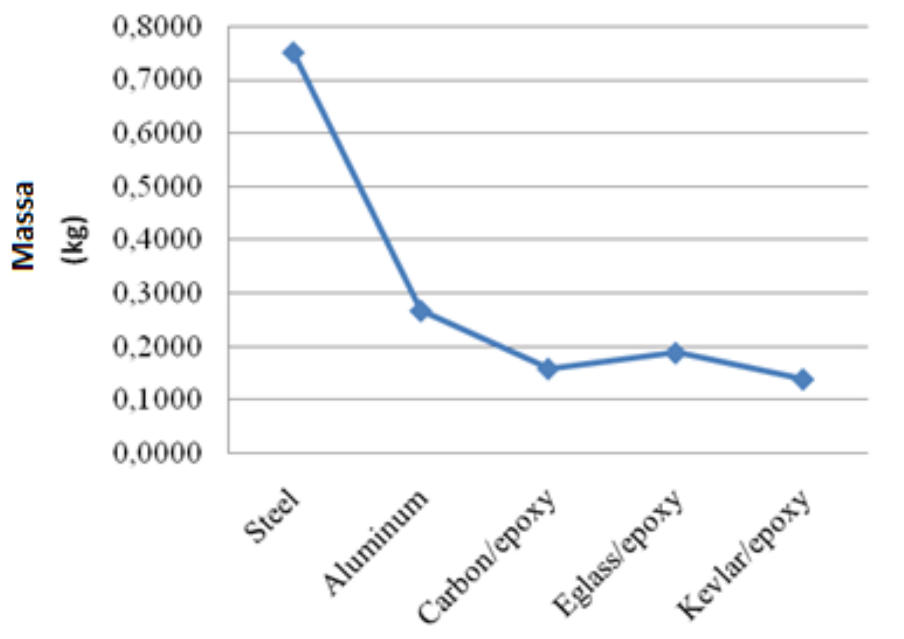

Gambar 7. Grafik masa Toe cap berdasarkan variasi bahan material

Hasil analisis tegangan menunjukkan variasi persebaran tegangan yang berbeda antara material isotropis dan material ortotropik. Toe cap berbahan steel dan aluminum memiliki sebaran tegangan yang mirip, yang berbeda hanyalah besarnya tegangan yang terjadi. Berdasarkan pada tegangan von mises maksimum, Toe cap berbahan e-glass epoxy memiliki nilai tertinggi, dan sedangkan mendapatkan nilai terendah. Grafik distribusi tegangan von mises maksimum dapat dilihat pada gambar 8 .

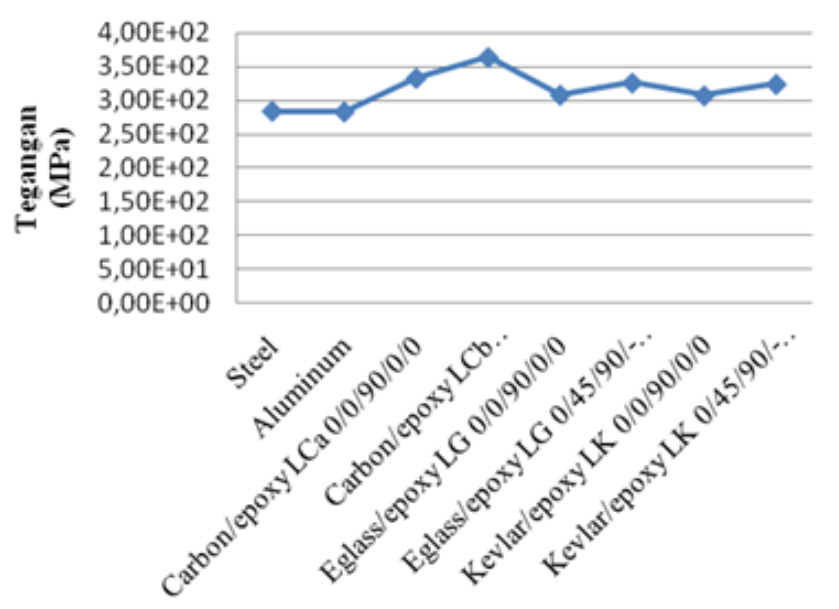

Gambar 8. Grafik tegangan von mises maksimum berdasarkan variasi 
Prediksi kegagalan Toe cap dengan pembebanan tekan dilakukan dengan menentukan nilai Margin of Safety (MS) dan Failure Indicies (FI). Hasil analisis menunjukkan bahwa Toe cap berbahan steel, aluminum, dan carbon/epoxy aman. Sedangkan Toe cap berbahan eglass/epox dan Kevlar/epoxy terdapat layer yang gagal (layer 5 \& 1). Kegagalan ini dikarenakan layer tersebut menerima beban yang paling besar diantara layer yang lainnya. Sehingga pada penelitian selanjutnya akan dilakukan kajian kegagalan dan cara mengatasinya, khususnya pada layer 5 dan 1 . Dan rencana kajian yang akan dilakukan adalah menambahkan ketebalan atau membuat variasi komposit hybrid. Untuk defleksi Toe cap dapat dilihat pada gambar 9 .

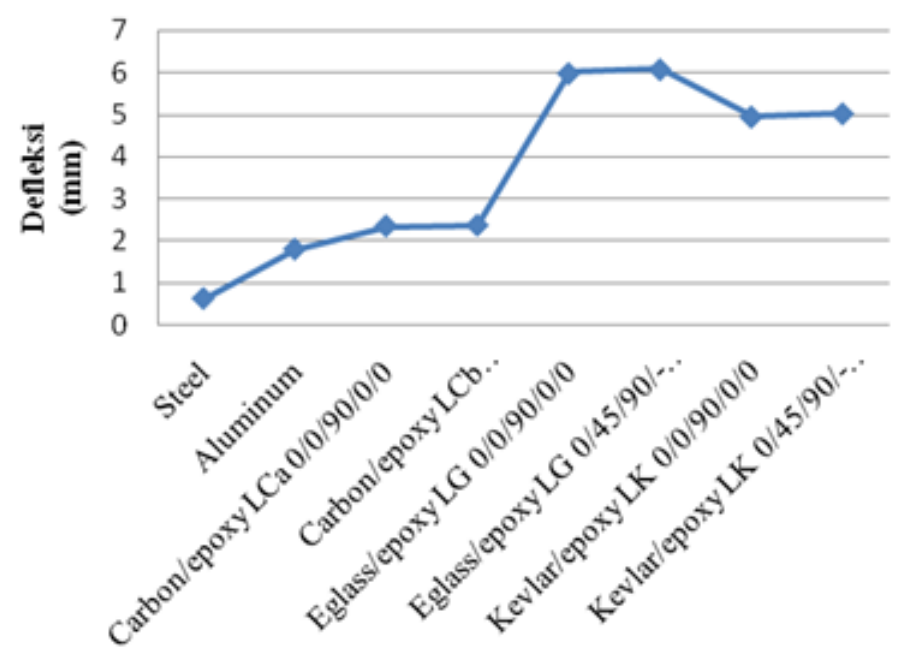

Gambar 9. Defleksi Toe cap berdasarkan variasi bahan material

Defleksi terbesar terjadi pada bahan e-glass epoxy sedang yang terkecil adalah pada bahan steel. Variasi besaran defleksi ini terjadi karena perbedaan nilai elastic modulus bahan. Ini dikarenakan besarnya kecilnya elastic modulus berbanding lurus dengan defleksi yang terjadi

\section{Kesimpulan}

Hasil kajian awal menunjukkan bahwa steel memiliki kemampuan yang paling baik menahan beban, namun memiliki masa yang paling berat. Carbon/epoxy adalah material komposi yang dalam analisis tegangan dinyatakan paling aman jika dibandingkan dengan komposit e-glass epoxy dan kevlas/epoxy. Ini dinyatakan dengan nilai FI yang dibawah angka 1. Pada bahan e-glass epoxy dan Kevlarlepoxy kegagalan terjadi pada layer 5 \&1, sedangkan layer 2, 3, dan 4 aman. Selain itu, carbon/epoxy juga memuliki masa yang rendah jika dibandingkan dengan material lain, hanya masih kalah ringan dengan Kevlar/epoxy. Sehingga material carbon/epoxy adalah pilihan utama dalam pembuatan Toe cap .

\section{DAFTAR PUSTAKA}

[1] Costa, Sérgio \& Peixinho, Nuno \& Mendonça, João. (2014). Numerical Simulation of Impact Events of the Ultimate Metallic Toe Cap Model for Safety Footwear. ASME International Mechanical Engineering Congress and Exposition, Proceedings (IMECE). 2. 10.1115/IMECE2014-39360.

[2] DW Nurhajati, A Yuniari, H Hardjaka, IN Indrajati, Analisa Toe cap Plastik Hasil Proses Cetak Injeksi, Prosiding Seminar Nasional Kulit, Karet dan Plastik, 2016 
[3] Ho, Mei-po \& Lau, Kin tak. (2012). Design of an impact resistant glass fibre/epoxy composites using short silk fibres. Materials \& Design. 35. 664-669. 10.1016/j.matdes.2011.10.003.

[4] Nuno PeixinhoNuno PeixinhoS. CostaJoão P. MendonçaJoão P. Mendonça Impact behaviour of safety shoe high strength steel parts, Engineering Transactions 66(2):175-185, January 2018

[5] P. Hema Aditya, K. Siva Kishore, D.V.V. Krishna Prasad, Characterization of Natural Fiber Reinforced Composites, International Journal of Engineering and Applied Sciences (IJEAS) ISSN: 2394-3661, Volume-4, Issue-6, June 2017.

[6] Rebecca Elwell, Jane Wigg, Microfine Toe cap s: An Innovative And Cost-Saving Solution, British Journal of Community Nursing 20 Suppl 4(Sup4):S30-6, 2015.

[7] Seçkin ERDEN, Mustafa ERTEKIN, Mechanical Evaluation Of A Composite Overshoe Protector, Tekstil ve Konfeksiyon 4(27):414, 2017.

[8] Yang, Eric \& Duhovic, Miro \& Lin, Richard \& Bhattacharyya, Debes. (2009). Finite Element Modelling and Analysis of Composites Toecaps. Iop Conference Series: Materials Science and Engineering. 4. 10.1088/1757899X/4/1/012010.

[9] Yizhuo Gu, Xuelin Tan, Zhongjia Yang, Min li, Zuoguang Zhang, Hot compaction and mechanical properties of ramie fabriclepoxy composite fabricated using vacuum assisted resin infusion molding, Materials \& Design (19802015), Volume 56, 2014, Pages 852-861.

[10] Personal protective equipment — Safety footwear (ISO 20345:2011).

[11] Undang-undang 1 Tahun 1970 tentang keselamatan kerja.

[12] Peraturan Menteri 5 Tahun 2018.

[13]PP No.88 Tahun 2019 Tentang Kesehatan Kerja.

[14] Performance-composite, http://www.performance-composites.com/carbonfibre/mechanicalproperties2.asp diakses pada Maret 2021.

[15] Mesh Convergence, https://knowledge.autodesk.com/support/inventor-nastran/learn explore/caas/CloudHelp/cloudhelp/2020/ENU/NINCAD-UsersGuide/files/GUID-834A66B2-3777-481D-BE28A741A60C6F17-htm.html, diakses pada Desember 2021.

[16] Regulasi K3 Baru : PP No. 88 tahun 2019 tentang Kesehatan Kerja, https://hsepedia.com/regulasi-k3-baru-pp-no88-tahun-2019-tentang-kesehatan-kerja/, diakses pada Desember 2021. 